\title{
Species Diversity of Stingless Bees (Hymenoptera: Meliponini) in Chili PEPPER (Capsicum annum L.) Plantation in West Sumatera
}

\author{
Dewirman Prima Putra ${ }^{1}$, Dahelmi ${ }^{2}$, Siti Salmah .M ${ }^{3}$, Etti Swasti ${ }^{4}$ \\ ${ }^{1}$ Departement of Agronomy, Faculty of Agriculture, Ekasakti University \\ ${ }^{2,3}$ Departement of Biology, Faculty of Science and Mathematics, Andalas University \\ ${ }^{4}$ Departement of Agronomy, Faculty of Agriculture, Andalas University
}

\begin{abstract}
Stingless bees are social insects like honey bees which can function as pollinator. Some of them can be pollinator in chili pepper plants which is very important role in increasing chili pepper production in West Sumatera. The objective of this research was to study the species diversity of stingless bees in chili pepper plantations in West Sumatera. Stingless bees were collected using insect net from nine districts/towns and in every district /town 2 sampled locations were determined. Results showed that there were three species of stingless bees found to visit chili pepper plantations, Trigona (Tetragonula) leaviceps Smith (58.85\%), T. minangkabau Sakagami et Inoue (40.18\%), and T.(Heterotrigona) itama cockerel (3.97\%). The species diversity was low with Shannon-Wiener index 0.82 , similarity indeks 0.75 and dominance indeks 0.475. There were two dominant species, T. leaviceps and T. minangkabau.
\end{abstract}

Keywords: species diversity, stingless bees, pollinator, chili pepper

\section{Introduction}

There are 41 species, one subspecies, and two forms of stingless bees (Meliponini) found in Indo-Malaya, and 18 species found in Sumatera (Sakagami et al. 1990). Sakagami and Inoue in 1987 reported that there were 23 species and one form of stingless bees found in central Sumatera. Species of stingless bees are distributed in primery and secondary forests, and in people settlements from low to high lands up to $1.500 \mathrm{~m}$ asl. (Salmah et al.1990).

Like honey bees (Apis spp), stingless bees (Trigona spp.) also function as pollinating insects. Due to their small body size, 2-14 mm (Sakagami et al. 1985, Osawa and Tsubaki 2003), stingless bees could obtain nectar from relatively small size flowers. Thus, stingless bees have more various foods compared to honey bees.

Chili pepper (Capsicum annum L.) can be planted in low and high lands (Sumarni and Muharam 2005). In West Sumatera chili pepper is a vegetable crop having important advantages, and even socially in Minangkabau society it is considered as primery crop. For this reason, chili pepper plantations or production centres can be found in many areas in West Sumatera. Due to widely distribution of chili pepper production centres and diverse species of stingless bees, it is very important to study the species diversity of stingless bees visiting chili pepper plantations in West Sumatera

\section{Materials and Methods}

\section{Study Areas}

Stingless bees were collected from chili pepper production centres located in nine districts/towns in West Sumatera: Lima Puluh Kota (1-2), Payakumbuh (3-4), Padang Panjang (5-6), Tanah Datar (7-8), Agam (9-10), Padang (11-12), Solok (13- 14), Pesisir Selatan (15-16), and Padang Pariaman (17-18)(Fig. 1). Two sampling locations were determined in each district/town. The samples were collected from November 2013 until April 2014. 


\section{International Journal of Science and Research (IJSR) \\ ISSN (Online): 2319-7064}

Index Copernicus Value (2013): 6.14 | Impact Factor (2015): 6.391

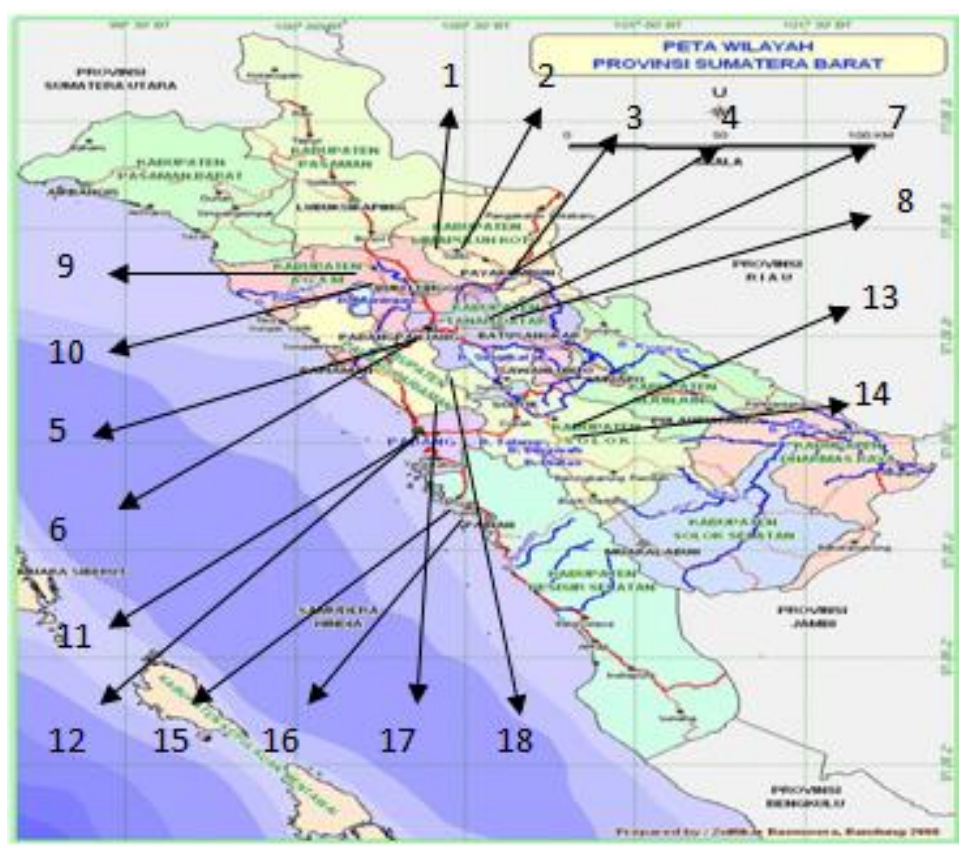

Figure 1: Locations from which stingless bees were collected in West Sumatera: 1.Koto Panjang Suluki, 2. Japang Manganti, 3. By Pass Payakumbuh, 4. Baringin, 5. Ganting, 6. Gunung, 7. Sabu, 8. Sikaladi, 9. Kubang Putiah, 10. Batutaba, 11. Kampung Dalam, 12. Lubuk Minturun, 13. Panyangkalan, 14. Batu Banyak, 15. Kubang Bayang, 16. Barangin Salido, 17. Kataping, 18. Lubuk Alung

\section{Methods}

Stingless bees were collected using scan sampling method (Martin and Bateson 1993) by counting the number of species and individuals visiting the flowers of chili pepper. Insects were collected in $10 \mathrm{~m}^{2}$ areas of plantations within 3 time periods: (7.00, 8.00, 9.00 a.m.), (10.00, $11.00,12.00$ a.m.), and (1.00, 2.00, 3.00 p.m.). In each time period the insects capture was done for 15 minutes. The capture was done in good and bright days.

\section{Species Identification}

Stingless bees collected were preserved in alcohol $70 \%$. They were then separated based on morphological characters using binokuler microscope. Identification to species level was conducted by using binokuler microscope completed with optilab

viewer. Refference books used for identification were Sakagami et al. 1990 and Michener 2007.

\section{Data Analysis}

Data analysis were done descriptively to the species of stingless bees and individual captured per time period. Diversity index based on Shannon-Wiener (Margurran 1988):

$$
\mathrm{H}^{\prime}=-\sum \mathrm{p}_{\mathrm{i}} \ln \mathrm{p}_{\mathrm{i}}
$$

$\left(\mathrm{H}^{\prime}=\right.$ Diversity index of Shannon-Wiener, $\mathrm{p}_{\mathrm{i}}=$ =proportion of number individuals of a species $i$ to total individuals $\left(n_{i} / N\right)$.

Criteria used to interprete diversity:

$$
\begin{aligned}
& \mathrm{H}^{\prime}<1=\text { low } \\
& \mathrm{H}^{\prime} 1-3=\text { middle } \\
& \mathrm{H}^{\prime}>3=\text { high }
\end{aligned}
$$

Dominance index was used to obtain information about dominant species in one community on each habitat. Dominance index used based on Simpson (Ludwig and Reynold 1988):

$\mathrm{D}=\sum\left(\mathrm{p}_{\mathrm{i}}\right)^{2}=\sum\left(\mathrm{n}_{\mathrm{i}} / \mathrm{N}\right)^{2}$

$(\mathrm{D}=$ Dominace index, $\mathrm{pi}=$ proportion of number individuals of a species i to total individuals

\section{Results}

There were 3 species of stingless bees identified from sampled chili pepper plantations in West Sumatera. They were Trigona (Tetragonula) leaviceps Smith, Trigona (Tetragonula) minangkabau Sakagami et Inoue and Trigona (Heterotrigona) itama Cockerell (Sakagami et al, 1990). It showed specific species in certain locations with different altitudes (Tabel 1). 


\section{International Journal of Science and Research (IJSR) ISSN (Online): 2319-7064 \\ Index Copernicus Value (2013): 6.14 | Impact Factor (2015): 6.391}

Table 1: Species of stingless bees and total individuals found in different locations in chili pepper production centres in West Sumatera

\begin{tabular}{|c|c|c|c|c|c|c|}
\hline \multirow{2}{*}{ No } & \multirow{2}{*}{ Location } & \multirow{2}{*}{ Altitute (m asl) } & \multicolumn{3}{|c|}{ Spesies of stingless bees } & \multirow[b]{2}{*}{$\begin{array}{c}\text { Total } \\
\text { individuals }\end{array}$} \\
\hline & & & $\begin{array}{c}\text { Trigona } \\
\text { Leaviceps }\end{array}$ & \begin{tabular}{|c|} 
Trigona \\
Minangkabau \\
\end{tabular} & $\begin{array}{c}\text { Trigona } \\
\text { itama }\end{array}$ & \\
\hline 1. & Koto Panjang Suliki & 650 & 49 & - & - & 49 \\
\hline 2. & Japang Manganti & 520 & 50 & - & - & 50 \\
\hline 3. & By Pass Payakumbuh & 600 & 62 & - & - & 62 \\
\hline 4. & Baringin & 600 & 37 & - & - & 37 \\
\hline 5. & Ganting & 740 & 51 & - & - & 51 \\
\hline 6. & Gunung & 760 & 54 & - & - & 54 \\
\hline 7. & Sabu & 910 & 53 & - & - & 53 \\
\hline 8. & Sikaladi & 880 & - & 60 & - & 60 \\
\hline 9. & Kubang Putiah & 900 & - & 40 & - & 40 \\
\hline 10. & Batu Taba. & 900 & - & 49 & - & 49 \\
\hline 11. & Kampung Dalam & 50 & 57 & - & - & 57 \\
\hline 12. & Lubuak Minturun & 30 & - & 61 & - & 61 \\
\hline 13. & Panyangkalan & 830 & - & 49 & - & 49 \\
\hline 14. & Batu Banyak & 800 & 43 & - & - & 43 \\
\hline 15. & Kubang Bayang & 100 & 36 & - & - & 36 \\
\hline 16. & Barangan Salido & 25 & - & - & 35 & 36 \\
\hline 17. & Kataping & 30 & - & 44 & - & 44 \\
\hline 18. & Lubuk Alung & 40 & - & 51 & - & 51 \\
\hline \multicolumn{3}{|c|}{ Total } & 492 & 354 & 35 & 881 \\
\hline \multicolumn{3}{|c|}{ Percentage } & 55.85 & 40.18 & 3.97 & 100 \\
\hline
\end{tabular}

T. leaviceps were captured in locations with altitudes range $50-910 \mathrm{~m}$ asl., temperature range $22-35{ }^{\circ} \mathrm{C}$ and humidity 32-78 \%. Locations for capturing T. minangkabau were 30$900 \mathrm{~m}$ asl., temperature range $21-35{ }^{\circ} \mathrm{C}$, and humidity $35-$ $78 \%$. The hive of stingless bees were found in stem and branch cavities, bamboo poles, house wall and stone cracks.

T. itama was found only in one location, in Barangan IV Jurai Subdistrict Pesisir Selatan, located at $25 \mathrm{~m}$ asl., temperature range $26-36{ }^{\circ} \mathrm{C}$ and humidity $38-64 \%$. Chili pepper plantations in which the stingless bees were captured were located in secondary forest and other horticultural habitats. Trigona leaviceps and T. minangkabau preferred to make hives in people settlements while $T$. itama preferred to do it in living trees. Field observation indicated that stingless bees visiting chili pepper plantations came from the hives near the plantations. It was found there were two plots of chili pepper about $100 \mathrm{~m}$ distance and both were located in the same line with stingless bee hives on which one plot was nearer to hive than another one. With this condition, intensity of stingless bees visits was higher in chili pepper plot closer to stingless bee hive compared to further one. Other observation indicated that when position of bee hive was opposite direction of two location of chili pepper plots, stingless bees only visited the closer plot but no visit to plot further to hive. Field observation also proved, if hives found in chili pepper plantation belonged to Trigona leaviceps, thus only the species found to visit the pepper plants. The same thing happened to species of T. Minangkabau.

Diversity index (H') of stingless bees in chili pepper plantations was 0.82 (low), Similarity Indeks was 0.75 (E= $0-1$ ) and Dominance Indeks was 0,475. There were two dominant species, $T$. leaviceps $(55.85 \%)$ and $T$. minangkabau (40.18\%).

Density of the three species of stingless bees based on observation time is shown in Fig. 2.

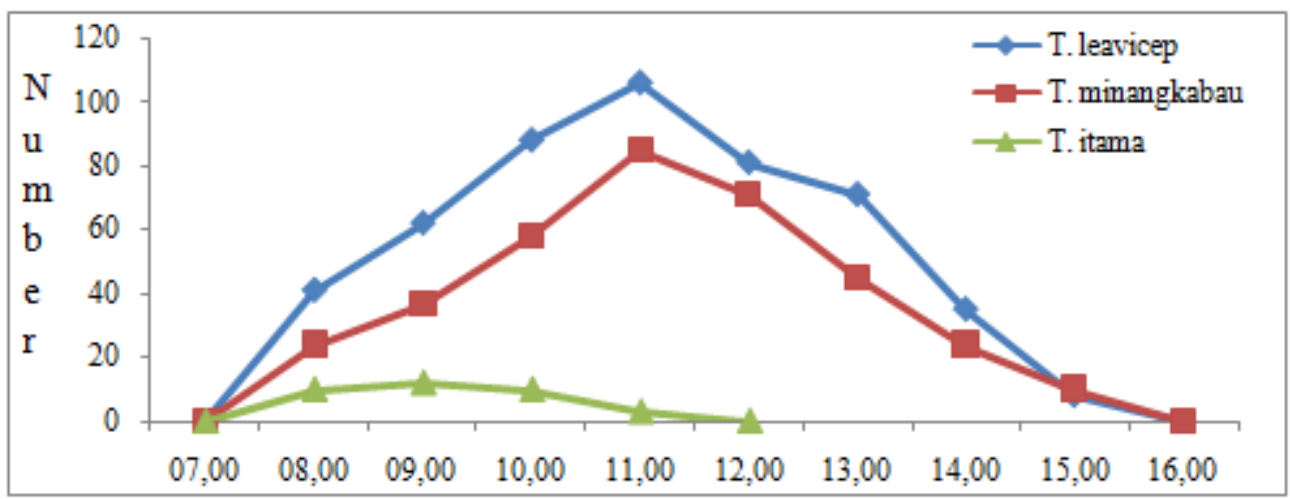

Figure 2: Stingless bees density in food searching activity

T.leaviceps and T. minangkabau were captured in chili plantations from 8.00 a.m until 3.00 p.m., while T. itama were captured from8.00 a.m. until 11.00 p.m.
The peak food searching time of $T$. leaviceps and $T$. minangkabau was at 11.00 a.m. (106 individuals of $T$. leaviceps and 85 individuals of $T$. minangkabau). The one for T. itama was at 09.00 a.m. 


\section{International Journal of Science and Research (IJSR) \\ ISSN (Online): 2319-7064 \\ Index Copernicus Value (2013): 6.14 | Impact Factor (2015): 6.391}

Stingless bees diversity visiting chili pepper besides being influenced by the presence of hives near location it was also affected by the presence of attractant. Chili pepper has nectar and pollen function as attractants. Although the sugar content of nectar was low in morning (37\%) but its volume was high enough $(0,2 \mathrm{ul})$. However, in day time sugar content of nectar was high (52\%) but its volume was low $(0,04 \mathrm{ul})$.
The peak of food searching activity of $T$. leaviceps and $T$. minangkabau occurred before day temperature reached maximum and relative humidity reached minimum, i.e. 12.00 a.m -13.00 p.m (Fig. 3).

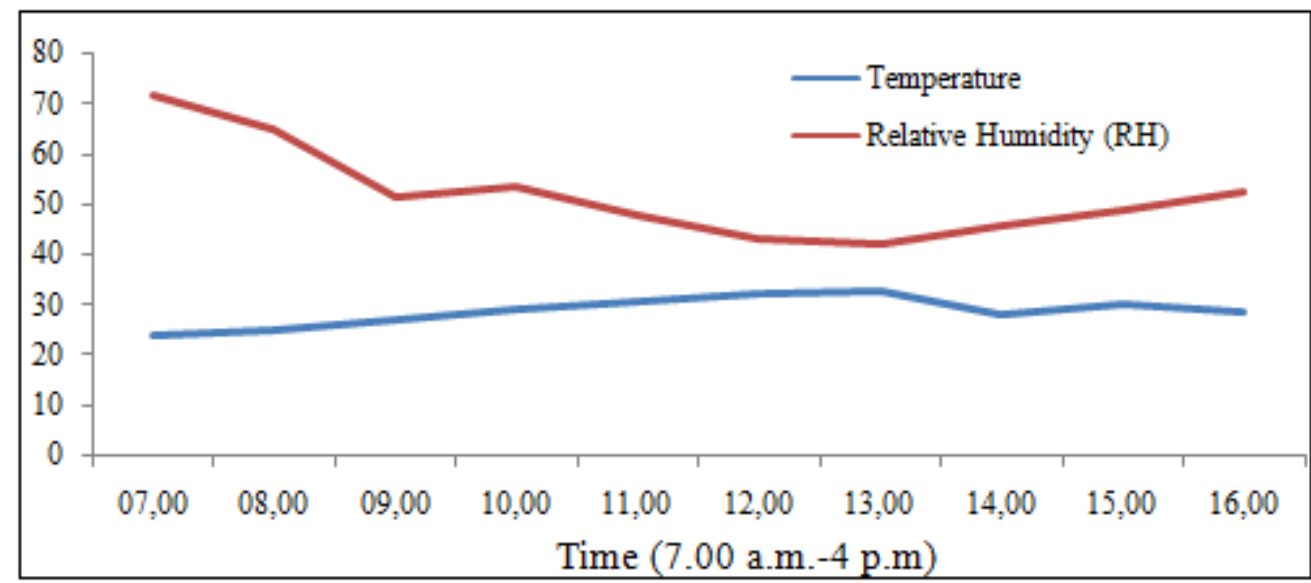

Figure 3: Temperature and humidity at the time of stingless bees captures

\section{Discussion}

There were 3 species of stingless bees captured in chili pepper plantations out of 23 species and one form found in West Sumatera (Salmah et al., 1990). The low species diversity of stingless bees $\left(H^{\prime}=0,82<1\right)$ visiting the chili pepper plants was assumed to cause by their short flight distance. Compared to honey bees capable of flying up to $1.5 \mathrm{~km}$ (Roubik and Aluja 1983), stingless bees could only fly as far as 100 - 200 m (Dollin, 2010). Roubik (1989) estimated the flight distance of stingless bees to search for food lees than $434 \mathrm{~m}$, and maximum $500 \mathrm{~m}$ (Bartareau, 1996). For $T$. carbonaria the flight distance for food searching was usually 25-30 m from their hives. Due to their limited distance flight to search for food, stingless bees could fly to the nearest food sources from their hives. On the other side, if the chili plantations were far from their hives, the stingless bee were not found there.

Stingless bees hives were found mostly in stem and branch cavities, poles made of bamboos, house cracks and also found in bridge structure cracks. Danaraddi et al. (2009) reported that the places where stingless bees made hives depent on their species, usually in tree and branch cavities, stone cracks, wall cracks, old dump, drums for storage.

Stingless bees diversity visiting chili pepper plantations besides being influenced by the presence or absence of hives near the plantations, it was also influenced by the presence of attractants. Chili pepper plants have attractants like nectar and pollen. Although the sugar content of nectar is low in the morning (37\%) but its volume is high enough (0,2 ul). In the day time nectar sugar content is high (52\%) but its volume is low (0,04 ul). Faegri and Van der Pijl (1979); Graham et al. (2006) elaborated that nectar is produced in nectaries gland which consist of 25-75 \% sugar with various amount of amino acid and fat.
The flower of chili pepper blossom (anthesis) three hours after the sun rises (Dag and Kammer, 2001; Cruz, 2005). At that time the volume of nectar is abundant $(0,2 \mu \mathrm{l})$ even though the content of sugar is low (37\%), therefore the visiting insects could obtain nectar easily. For this reason, in the morning there are more pollinating insects visit flowers and reach the peak at 11.00 a.m. On the other hand, at the day time the volume of nectar reduces $(0,04 \mu \mathrm{l})$ even though the sugar content increases (52\%), thus it will cause the pollinators difficult to obtain nectar and as a consequence the number of pollinators visiting flowers decreases.

The high volume of nectar in the morning is caused by low atmosphere temperature and high humidity. Under this condition the nectar has not evaporated yet. As the temperature increases and humidity decreases the nectar evaporates and cause the volume of nectar decreases in the day time and the number of insects visiting the flowers also decreases. Kwapong et al. (2010) indicated that the visit of insects to flowers in their activity of searching for food was influenced by weather condition such as temperature, humidity, and wind speed.

\section{Conclusion}

Diversity of stingless bees visiting chili pepper plantations consisted of three species, Trigona (Tetragonula) leaviceps Smith, Trigona. (Tetragonula) minangkabau Sakagami et Inoue and Trigona (Heterotrigona) itama Cockerell). Stingless bees visiting the plants were the ones having hives near plantations. The presence of stingless bees in chili pepper plantations besides having hives near locations, it was also determined by the presence of attractants like nectar and pollen. Activity of searching food for T.leaviceps and T. minangkabau occurred from 08.00 a.m- 3.00 p.m with the peak at 11.00 a.m., and for T. itama occurred from 08.00-11.00 a.m local time. 


\section{International Journal of Science and Research (IJSR) \\ ISSN (Online): 2319-7064}

Index Copernicus Value (2013): 6.14 | Impact Factor (2015): 6.391

\section{References}

[1] Sakagami S.F, Inoue T, and S. Salmah.1990. Stingless bees of Central Sumatra. In Sakagami S.F, Ohgushi R, Roubik D.W, (eds). Natural history of social wasps and bees in equatorial Sumatra. pp. 125-137. Hokkaido University Press; Sapporo, Japan.

[2] Sakagami, S.F. and T. Inoue (1987). Stingless Bees of the genus Trigona (subgenus Trigonella) with notes on the reduction of spatha in male genitalia of the subgenus Tetragonula (Hymenoptera, Apidae). Kontyû 55: 610627.

[3] Salmah, S., T. Inoue, and S.F. Sakagami. 1990. An analysis of apid bee richness (Apidae) in Central Sumatra. Dalam Sakagami, S.F., R. Ogushi, dan D.W. Roubik (eds.), Natural History of Social Wasps and Bees in Equatorial Sumatra, hal. 139-174. Hokkaido Univ. Press, Sapporo, Japan.

[4] Sakagami, S. F., Inoue, T. and Salmah, S. 1985. Key to the stinglessbee species found or expected from Sumatra. In: (Ohgushi R.I, ed.).. Evolutionary Ecology of Insect in Humid Tropics, Especially in Central Sumatra. Kanasawa University, Japan. Sumatra Nature study (Entomology), pp. 37-43

[5] Osawa, N., and Y. Tsubaki, 2003. Seasonal variation and community structure of tropical bees in a lowland tropical forest of peninsular Malaysia : the impact of general flowering. Springer.-Verlag. Pp. 315-324

[6] Sumarni N dan Muharam A. 2005. Cultivation of Chili Pepper. Vegetable Crops Research Lembang- Bandung.

[7] Martin P. and Bateson P., 1993, Measuring Behaviour: An Introductory Guide.Ed ke 2. Cambrige Univ. Press, Cambrige.

[8] Michener, C. 2007. The bees of the world. Johns Hopkins University Press, Baltimore, Maryland, USA.

[9] Magurran, A. E. 1988. Ecological Diversity and its Measurement. Princeton University Press, Princeton, NJ.

\section{Appendix}

Characteristic feature of Trigona (Tetragonula) leaviceps Smith

Posterior fringe of hind tibia mosly consisting of flumose hairs, wing venation less reduced, pterostigma narrower. Body 4-4,5 $\mathrm{mm}$ average 4,4 \pm 0,2 $\mathrm{mm}$ and wing 4,5-5,0 $\mathrm{mm}$ average 4,6 \pm 0,2 $\mathrm{mm}$ with hamuli 5. Body color blackish brown

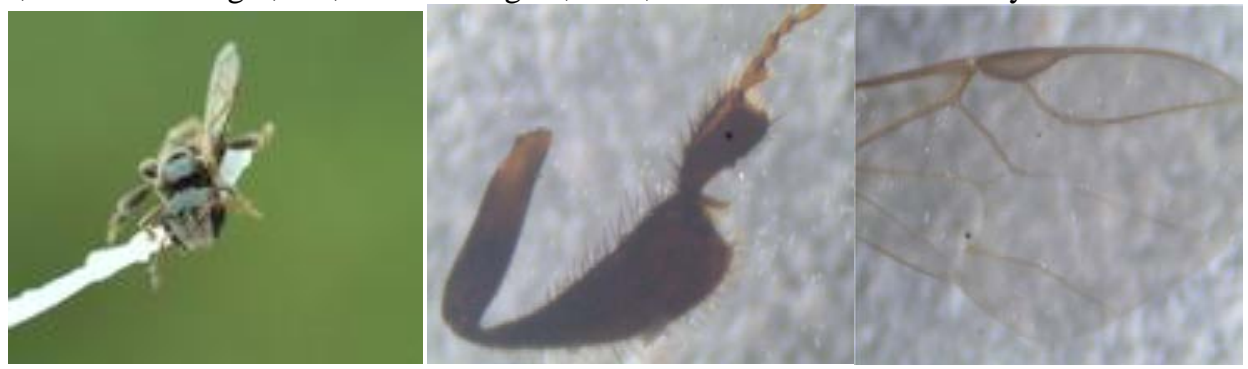

Figure 4: Worker T. leaviceps, Hind tibia and wing venasi

Characteristic feature of Trigona (Tetragonula) minangkabau Sakagami et Inoue

Posterior fringe of hind tibia mosly consisting of flumose hairs, wing venation less reduced, pterostigma narrower. Body 3,2 3,5 $\mathrm{mm}$ average 3,3 $\pm 0,2 \mathrm{~mm}$ and wing 3,5 - 4,0 $\mathrm{mm}$ average 3,8 $\pm 0,3 \mathrm{~mm}$ with hamuli 5 . Metasoma predominantly chestnut brown.
[10] Ludwiq, J.A., and J. F. Reynolds, 1988. Statistical Ecoloqy a Primer on Methods and Computing. John Wiley \& Sons, New York.

[11] Roubik D.W dan Aluja M. 1983. Flight ranges of Melipona and Trigona in Tropical forest. J Kansas Entomol Soc 56: 217-222.

[12] Dollin A. 2010. Stingless beekeeping around the world. Aussie Bee Special 1-5

[13] Roubik, D.W. 1989. Ecology and Natural History of Tropical Bees. University Press, Cambridge.

[14] Bartareau T. 1996. Foraging behaviour of Trigona carbonaria (Hymenoptera: Apidae) at multiple choice feeding stations. Australian Journal of Zoology 44: 143153.

[15] Danaraddi, C. S.; Viraktamath, S.; Basavanagoud, K. and Bhat, A. R. S. (2009). Nesting habits and nest structure of stingless bee, Trigona iridipennis Smith at Karnataka Karnataka Journal of (2): 310-313.

16] Faegri, F. \& van der Pijl, L. 1971. The Principles of Pollination Ecology. .Pergamon Press, Oxford.

Graham, L. E., J. M. Graham and L. W. Wilcox. 2006. Hall.

[18]Dag, A. \& Kammer, Y. 2001. Comparison between the effectiveness of honey bee (Apis mellifera) and bumble bee (Bombus terrestris) as pollinators of greenhouse sweet pepper (Capsicum annuum). American Bee Journal, v.141, p.447-448.

[19] Cruz D. de O., Freitas B.M., Silva L.A. da, Silva S.E.M. da, Bomfim I.G.A. 2005. Pollination efficiency of the stingless bee Melipona subnitida on Green-house sweet pepper, Pesq. Agropec. Bras., Brasilia 40, 1197-1201.

Kwapong P., K. Aidoo, R. Combey dan A. karikari. Utilisation. A Training Manual For Stingless Beekeeping Unimax Macmillan LTD. 


\section{International Journal of Science and Research (IJSR) \\ ISSN (Online): 2319-7064}

Index Copernicus Value (2013): 6.14 | Impact Factor (2015): 6.391

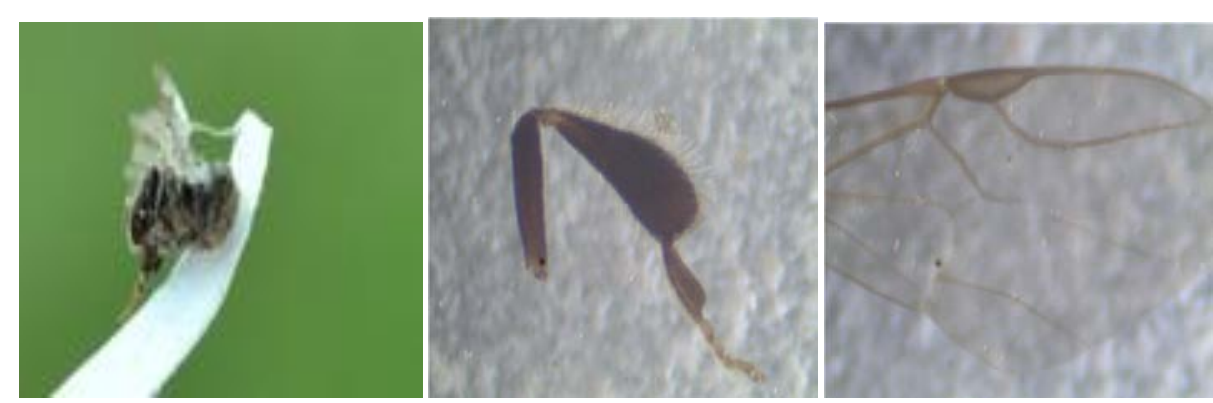

Figure 5: Worker T. minangkabau, Hind tibia and wing venasi

Characteristic feature of Trigona (Heterotrigona) itama Cockerell Body 5,5 - 6,0 $\mathrm{mm}$ average 5,9 \pm 0,2 $\mathrm{mm}$ and wing 6,0 $6,5 \mathrm{~mm}$ average $6,4 \pm 0,2 \mathrm{~mm}$ with hamuli 7. Posterior fringe of hind tibia mosly consisting of flumose hairs, hind basitarsus about $2 / 3$ hind tibia and black body color. Left mandible with one weak tooth.

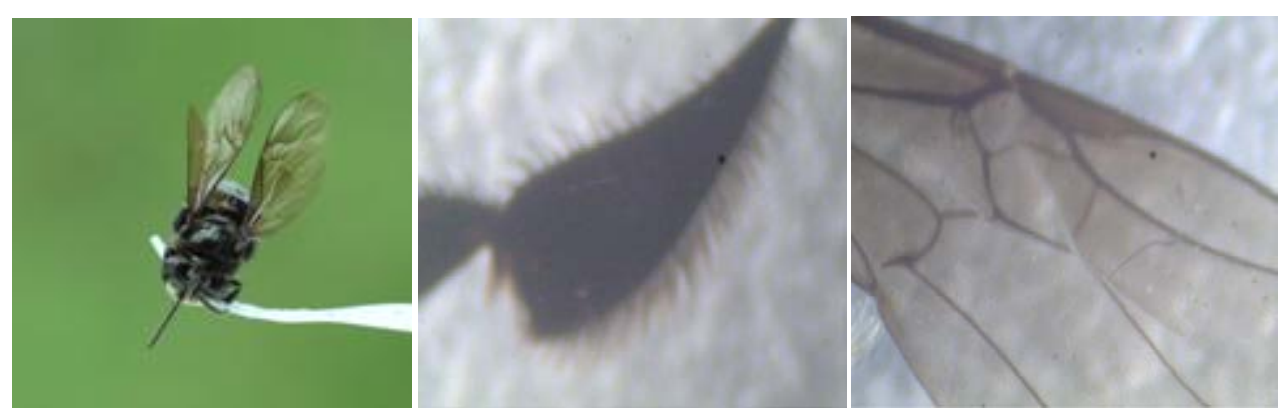

Figure 5: Worker T. itama, Hind tibia and wing venasi 